\title{
Response of tillage practices and farm yard manure on soil health, growth, yield and nutrient uptake by potato (Solanum tuberosum L.) cv. KUFRI BADSHAH
}

\section{VISHESH KUMAR, T. THOMAS AND SUSHIL KUMAR}

Received : 26.03.2015; Revised : 29.04.2015; Accepted : 09.05.2015

\section{MEMBERS OF RESEARCH FORUM}

Corresponding author : VISHESH KUMAR, Department of Soil Science, Allahabad School of Agriculture, Sam Higginbottom Institute of Agriculture, Technology and Sciences, ALLAHABAD (U.P.) INDIA

Email: visheshchauhan.ag@gmail.com

\section{Co-authors :}

T. THOMAS, Department of Soil Science, Allahabad School of Agriculture, Sam Higginbottom Institute of Agriculture, Technology and Sciences, ALLAHABAD (U.P.) INDIA

SUSHIL KUMAR, Department of Agricultural Chemistry and Soil Science, C.C.R. (P.G.) College, MUZAFFARNAGAR (U.P.) INDIA

\section{Summary}

The field experiment was conducted during Rabi season 2011-12. This study evaluated the effects of tillage and FYM on soil health, growth and yield in south Allahabad, Uttar Pradesh. The experimental consisted of 9 treatments laid out in Randomized Block Design with three replications, three levels of tillage $(10,20$ and $30 \mathrm{~cm})$ and FYM $\left(0,15\right.$ and $\left.30 \mathrm{t} \mathrm{ha}^{-1}\right)$. The observations of crop were taken at 30,60 and 90 DAS (Days after sowing). All levels of tillage and FYM, improved the soil physical and chemical properties but best performance was recorded in $\mathrm{T}_{8}$ (Depth of tillage at $30 \mathrm{~cm}+\mathrm{FYM}_{\text {at }} 30 \mathrm{t} \mathrm{ha}^{-1}$ ). All growth parameter and yield was found statistically significant. The maximum plant height $(18.40,38.63$ and $56.86 \mathrm{~cm}$, respectively), number of branches $\left(5.16,11.30\right.$ and 13.86) and leaves plant ${ }^{-1}(21.30,68.63$ and 91.76) was found in treatment $8\left(\mathrm{~T}_{8}\right)$ and maximum tuber yield $\left(44.83 \mathrm{tha}^{-1}\right)$ was also recorded in $\mathrm{T}_{8}$, where depth of tillage at $30 \mathrm{~cm}+\mathrm{FYM}$ at $30 \mathrm{t} \mathrm{ha}^{-1}$.

Key words : Tillage practices, FYM, Potato, Soil properties, Yield attributes

How to cite this article : Kumar, Vishesh, Thomas, T. and Kumar, Sushil (2015). Response of tillage practices and farm yard manure on soil health, growth, yield and nutrient uptake by potato (Solanum tuberosum L.) cv. KUFRI BADSHAH. Asian J. Soil Sci., 10(1) : 108-113. 